A. B. Olkhovska, V. V. Malyi

National University of Pharmacy

\title{
THEORETICAL AND METHODOLOGICAL APPROACHES TO DEVELOPMENT OF THE "ROAD MAP" FOR PROMOTING A NEW MEDICINE PRODUCT TO THE PHARMACEUTICAL MARKET
}

The aim of the article is to develop theoretical and methodological approaches to composing the "road map" to promote a new medicine product (MP) to the market. The methodological basis of the research is the statements of the Ministry of Health of Ukraine, analytical companies of the pharmaceutical market, scientific publications and reports. During the research we used the following methods, namely: marketing, system-based and analytical, modeling, logical analysis and generalization, structural grouping, "road mapping".

Results and discussion. The article indicates that "road maps" are one of the most effective tools for solving problems to enhance innovative potential and for improving the process of making strategic decisions to promote a new MP to the market, which are successfully applied by a number of foreign high-tech companies. We have developed the model of the "road map" for promoting a new MP to the pharmaceutical market, as well as detailed implementation of its stages.

Conclusions. The model of the "road map" was developed to promote a new MP to the market, the implementation of which will ensure pharmaceutical enterprises to effectively market the product, by taking strategic decisions on defining the communicative and economic efficiency of the promotion process. We have proposed the methods of risk modeling while implementing the "road map" model for promoting MP to the market.

Key words: medicine product; pharmaceutical market; "road map"; model; promotion, marketing communications

\author{
А. Б. ОльховськА, В. В. МАлий \\ Національний ббарлацевтичний університет
}

\section{ТЕОРЕТИЧНІ ТА МЕТОДИЧНІ ПІДХОДИ ДО РОЗРОБКИ «ДОРОЖНЬОЇ КАРТИ» ПРОСУВАННЯ НОВОГО ЛІКАРСЬКОГО ЗАСОБУ НА ФАРМАЦЕВТИЧНИЙ РИНОК}

Метою роботи $є$ розробка теоретичних та методичних підходів до складання «дорожньої карти» просування нового лікарського засобу (ЛЗ) на ринок. Методологічну основу дослідження склали звіти MO3 України, аналітичних компаній фармацевтичного ринку, наукові публікації та доповіді. У процесі дослідження використовувалися такі методи: маркетингові, системноаналітичні, моделювання, логічного аналізу та узагальнення, структурного групування, дорожнього картування.

Результати та їх обговорення. У статті зазначено, що одним з найбільш ефективних інструментів вирішення завдань з активізації інноваційного потенціалу та вдосконалення процесу прийняття стратегічних рішень 3 просування на ринок нового ЛЗ є «дорожні карти» (road maps), які успішно застосовуються рядом зарубіжних високотехнологічних компаній. Розроблено модель «дорожньої карти» просування нового лікарського засобу на фармацевтичний ринок та деталізована практична реалізація їі етапів.

Висновки. Розроблено модель «дорожньої карти» просування нового лікарського засобу на ринок, практична реалізація якої дозволить фармацевтичним підприємствам ефективно просувати товар на ринок, поетапно приймаючи стратегічні рішення з визначенням комунікативної та економічної ефективності процесу просування. Запропоновані методи моделювання ризику при практичній реалізації моделі «дорожньої карти» просування лікарських засобів на ринок.

Ключові слова: лікарський засіб; фармацевтичний ринок; «дорожня карта»; модель; просування; маркетингові комунікації 


\author{
А. Б. ОльХовскАЯ, В. В. МАлЫЙ \\ Национальный фбарлацевтический университет
}

\title{
ТЕОРЕТИЧЕСКИЕ И МЕТОДИЧЕСКИЕ ПОДХОДЫ К РАЗРАБОТКЕ «ДОРОЖНОЙ КАРТЫ» ПРОДВИЖЕНИЯ НОВОГО ЛЕКАРСТВЕННОГО СРЕДСТВА НА ФАРМАЦЕВТИЧЕСКИЙ РЫНОК
}

Целью работы является разработка теоретических и методических подходов к составлению «дорожной карты» продвижения нового лекарственного средства (ЛС) на рынок. Методологическую основу исследования составили отчеты МЗ Украины, аналитических компаний фармацевтического рынка, научные публикации и доклады. В процессе исследования использовались следующие методы: маркетинговые, системно-аналитические, моделирования, логического анализа и обобщения, структурной группировки, дорожного картирования.

Результаты и их обсуждение. В статье указано, что одним из наиболее эффективных инструментов решения задач по активизации инновационного потенциала и совершенствования процесса принятия стратегических решений по продвижению на рынок нового ЛС являются «дорожные карты» (road maps), которые успешно применяются рядом зарубежных высокотехнологических компаний. Разработана модель «дорожной карты» продвижения нового лекарственного средства на фармацевтический рынок и детализированная практическая реализация ее этапов.

Выводы. Разработано модель «дорожной карты» продвижения нового лекарственного средства на рынок, практическая реализация которой позволит фармацевтическим предприятиям эффективно продвигать товар на рынок, поэтапно принимая стратегические решения по определению коммуникативной и экономической эффективности процесса продвижения. Предложены методы моделирования риска при практической реализации модели «дорожной карты» продвижения лекарственных средств на рынок.

Ключевые слова: лекарственное средство; фармацевтический рынок; «дорожная карта»; модель; продвижение; маркетинговые коммуникации

\section{STATEMENT OF THE PROBLEM}

The health care of people is a priority for the pharmaceutical sector of healthcare, whose innovative development is a key to realization of its socioeconomic function. This idea was confirmed in the strategy of development of high-tech industries of Ukraine until 2025 (agro-industrial complex, pharmaceutical industry and medical services) [1].

In 2017, 759 enterprises were engaged in innovation activity in industry, with $53.8 \%$ enterprises manufacturing basic pharmaceutical products and chemicals, which generally launched only $7.8 \%$ of innovative products [2].

In such conditions, a priority is given to intensifying innovation and investment processes at all stages of the life cycle of the medicine product (MP), as well as to improving the process of making strategic decisions on the development and introduction of an innovative MP to the market. "Road maps" are one of the most effective tools for solving these problems, which are successfully used by a number of foreign high-tech companies in almost all industries [3-6].

\section{ANALYSIS OF RECENT RESEARCH AND PUBLICATIONS}

Over the past ten years, a number of scientific studies have been carried out on the aspects of arrangement and management of innovation processes in pharmacy [7-9]; substantiation of cost effectiveness and commercial expediency to introduce a new medicine and financing development of new MP as long-term investment projects $[10,11]$; determining the role of the innovation factor in the economic growth of pharmaceutical enterprises and the theoretical foundations and methodological substantiation of a complex analysis and modeling of expediency and effectiveness of development of new MP $[12,13]$ and the main functional blocks of the organizational and technological process of development of a new medicine [14].

\section{IDENTIFICATION OF ASPECTS OF THE PROBLEM UNSOLVED PREVIOUSLY}

Thus, today occasional were scientific studies on promoting a new MP to the market with the development of its "road map" in terms of marketing communications, which requires a concretized general concept of the "road map" and its structural components.

\section{OBJECTIVE STATEMENT OF THE ARTICLE}

The aim of the article is to develop of theoretical and methodological approaches to composing the "road map" for promoting a new MP to the market.

The methodological basis of the research is the statements of the Ministry of Health of Ukraine, analytical companies of the pharmaceutical market, scientific publications and reports. During the research we used the following methods, namely: marketing, system-based and analytical, modeling, 
logical analysis and generalization, structural grouping, road mapping.

\section{PRESENTATION OF THE MAIN MATERIAL OF THE RESEARCH}

Generics amount to $91 \%$ of MPs in the pharmaceutical market of Ukraine, with innovative drugs represented insufficiently. Thus, their share in the monetary equivalent is about $9 \%$, and almost all of them are imported ones [15].

Today in various countries of the world there are more than 5,000 new prospective MP being developed, with most of them still at the non-clinical study stage.

In these conditions, focus is placed on the intensified innovative and investment component of the product life cycle and the process of making strategic decisions on the development and marketing of innovative MPs.

One of the most effective tools for solving these problems is "road maps". The first "road maps" were [3]:

- corporate, developed by Motorola and Philips in the early 1990's;

- sectorial, launched in 1992 in the field of semiconductor industry of the USA, and are being developed up to the present day;

- international, operating since 1997 and funded by international consortia and national industrial associations of the USA, Europe, Japan, Korea, Taiwan, etc.

In the American terminology, the "road map", in one of the figurative meanings, is a "plan for moving further; plan for the future, visual representation of the scenario of development, etc." [16].

Today, the range of "road map" application is wide and covers not only business, but also other types of management activities, including state management. Thus, at the national level, the Cabinet of Ministers of Ukraine published the "road maps" with respect to [17-20]:

- Sustainable Development Strategy Ukraine 2020;

- access to MP and vaccines for 2019-2023 Comprehensive Support for Access to Medicine Products and Vaccines;

- the memorandum on the intentions of cooperation to implement a transparent and effective electronic healthcare system in Ukraine;

- Health 2020 strategies - a new European policy and strategy in the interests of public health. Success of the identified "road maps" as a marketing strategy depends on the effective implementation of their provisions into the practical activities of the relevant industries (in this case, healthcare), sectors (medical and pharmaceutical) and, directly, enterprises of the branch and structural subdivisions.
In order to specify the above idea, our task is to model the effective marketing strategy of promoting a new MP to the pharmaceutical market, the application of which enables, firstly, to optimize the selection and implementation of marketing research at the analytical stage; secondly, to use the most effective and least costly methods of promotion by means of separate marketing communication tools at the stage of promoting MP to the market and, thirdly, to minimize the cost of MP for the end user. To perform this task, we have developed a model of the "road map" for promoting MP to the pharmaceutical market, which consists of four successive stages (Fig.).

We are going to detail each stage of the model. The first stage, which consists of two components a comprehensive study of the pharmaceutical market and incidence of the disease of a certain nosology - involves a substantiated information array on the following issues, namely:

- the market situation (volume and growth rate of the market, the ratio of innovative MP and generics in the market, prescribed and non-prescribed MPs, available channels of promotion, their efficiency, financial solvency of consumers, its tendencies);

- incidence of the disease, cured with the MP which is being promoted to the market. This array of information can be generated by a complex analysis of various sources, namely: statements of the WHO, the Ministry of Health of Ukraine and analytical companies of the pharmaceutical market, scientific publications and reports at congresses, symposiums, conferences, etc.

Thus, according to the results of the first stage of the model, a strategic decision can be made regarding the demand of the MP in the pharmaceutical market.

The second stage involves a comprehensive marketing research directly as a market characteristic of this MP, as well as its relevant environmental factors. This stage is a key to further implement the model stages, since it decides on the feasibility of promoting a new MP to the market, thus, the complex of studies of this stage should include:

- customer-based analysis (of distributors and pharmacy networks);

- segmentation of the market, which enables to identify prospective consumers as a target group focused on the consumption of the MP;

- positioning of the MP which we propose to perform according to such characteristics as efficiency and safety of the product, its composition, pharmaceutical form, dosage, price, manufacturer and even packaging and its design. In other words, all those characteristics which position the MP as more competitive than its analogues in the market;

- analysis of the internal and external competitive environment of the MP, which involves complex 


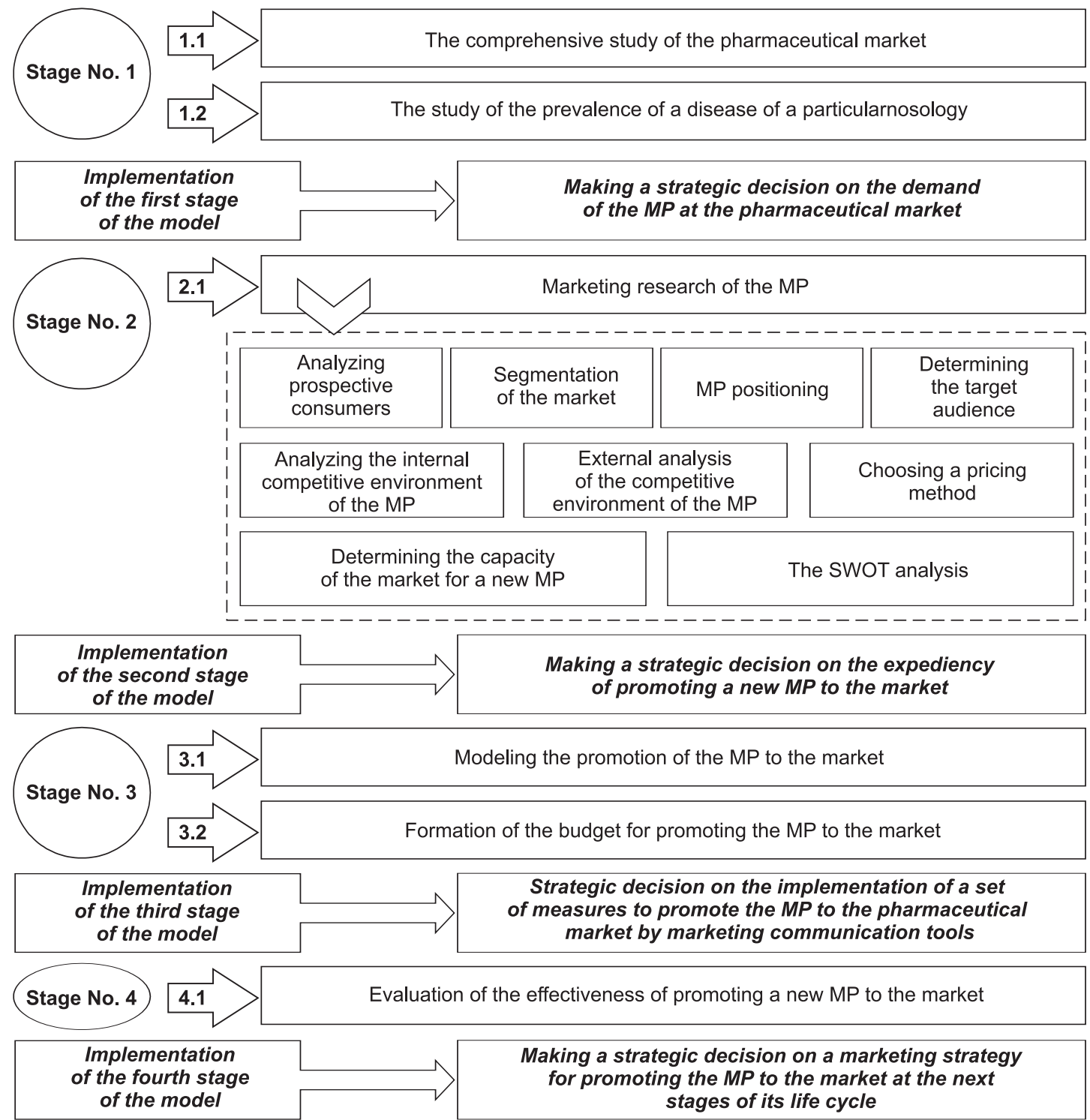

Fig. The "road map" model of promoting a new MP to the pharmaceutical market

Source: original development

studies of the assortment line of MP, which are positioned in the market as products to cure the disease of the same nosology as the new MP;

- forming the optimal retail price of a new MP is the key issue of this stage, since today solvency of consumer demand for pharmaceutical products is quite low and tends to further decrease. In order to realize the social function of medicines as a commodity, the pharmaceutical market can apply the following pricing methods [21, 22], namely:

- Peter van Westendorp's method (PSM (Price Sensitivity Meter)) as a method which is clearly focused on demand and its flexibility;

- BPTO method (Brand-Price Trade-Off), which is applied to identify the following elements of the competitive and price position of the test product, in this case, the sensitivity of the market to the altered price of the MP, promoted to the market and the price level, which will be more competitive than the analogous products; - conjoint analysis as a method which takes into account the benefits of consumers and allows to determine the impact of individual product characteristics on the decision to purchase the MP; - determining the market capacity for the MP, which enables to develop an effective promotion strategy, calculate the optimum amount of its production and, in general, ensures a high economic effect to all participants of promoting the MP to the market.

According to the results of the second stage of the model, a strategic decision is made regarding the expediency of promoting the MP to the market.

Component 3.1 of the third stage of the model Promotion modeling provides for the development of an optimal marketing plan to promote the MP 
to the market with the involvement of the most effective marketing communications for the MP. We recommend that the effectiveness of the selected promotion methods and tools of marketing communications be determined by the expert evaluation method when experts are represented by three groups: doctors (ranking therapeutic efficacy), pharmaceutical workers and consumers (identifying prospective and real demand), marketers of marketing and sales departments of the pharmaceutical manufacturer (making their proposals on volumes of production).

Component 3.2 of the model - Formation of the budget of promotion also requires an expert assessment of the promotion methods and tools of marketing communications with a possible range from 1 (maximum financial effect) to 0 (the minimum efficiency of the promotion method).

Implementing the indicated components of the third stage of the model enables to make a strategic decision on the implementation of a complex of marketing communications for the promotion of the MP to the pharmaceutical market.

At the fourth stage - Evaluation of the effectiveness of the promotion of new medicine products to the market, we suggest determining the criteria for communicative and economic efficiency. In order to implement this stage of the "road map" model for promoting the MP to the market, a pharmaceutical enterprise should thoroughly and consistently analyze all the previous stages of the "road map" of the process of promoting the MP to the market. Since the effects of communicative measures are varied and difficult to measure, we suggest using such indicators as communicative effectiveness which determines the impact of a marketing message on the target audience and enables to quantitatively measure such criteria as spontaneous knowledge of the MP as a percentage of consumers, being aware of this trade mark without its previous mention and knowledge of the MP as a representative of a certain pharmacotherapeutic group. Successful marketing communications, as a rule, results in purchasing the MP, transforming communicative efficiency into economic one.

Economic efficiency is determined by the increased profit after implementing all stages of the model, and can be calculated quantitatively (in monetary terms) as the ratio of actual sales to the cost of the promotion.

Thus, assessment of the effectiveness of promoting a new MP to the market is a result of the communicative and economic effects. In the pharmaceutical sector, the complex character of determining the effect of measures to promote a new MP is due to the specific characteristics of this process, namely:

- promotion is one of the factors affecting the final marketing results. An important role is played by other elements of the marking complex, macrofactors and others;
- the behavior of a particular consumer of pharmaceutical products is individual, and it may be different when the same factors influence the target audience.

Thus, according to the results of the final stage of the model, a strategic decision is taken regarding the marketing strategy for promoting the MP to the market at the next stages of its life cycle.

It should be emphasized that every stage of the "road map" model for promoting the MP to the market has certain economic risks, for the accurate assessment of which one should use a quantitative analysis of their measurement. The most common methods of risk assessment are as follows:

- risk assessment when determining the discount rate. Thus, the works $[11,14]$ suggest that the capability of a particular investment project is confirmed by calculations of the main economic indicators, namely: discounted pay-back period (DPB), net present value (NPV) of cash flow, internal rate of return (IRR), return on investment (ROI). Thus, for example, the economic effect can be adjusted, provided that the recommended interest rate is taken into account, including the remuneration for the risk by its category and market situation. The theory and practice of innovation projects involves the following categories and risk situations: the first category is deep penetration into the market (interest rate of $10 \%$ ); development and promotion of a new product is the second category (15\%); third and fourth categories are expansion of the market boundaries and diversification of production and sales ( $25 \%$ and $30 \%$ respectively). That is, the higher the level of risk, the more the targeted profit to compensate for this risk [23];

- the scenario method. During the analysis of the possible development of events in the market, there are several scenarios, namely: optimistic, pessimistic, and nominal. Then, one should determine the expert method or calculate the probabilities (by the statistical method) of the selected scenarios of the development of events and the possible effects of each scenario separately, depending on the possible combinations of impact factors. The expected effect value is also calculated as an average one by the probable scenarios;

- comparison of costs and results. To assess the risk of implementing the "road map" model, one should compare its expected results and possible losses in the implementation of the risk situation (not achieving planned sales, lowering the solvency of consumer demand, interference of competitors, etc.). The results of the evaluation are used to make decisions on the feasibility of implementing the model, based on the following indicators of the ratio $(\mathrm{K})$ of the probable loss potential $\left(\mathrm{V}_{\mathrm{V}}\right)$ to the amount of funds spent to promote the MP to the market $\left(\mathrm{V}_{\mathrm{P}}\right)$ : acceptable $-\mathrm{K} \leq 0.25$; permissible $\mathrm{K} \leq 0,50$; critical $-\mathrm{K} \leq 0,75$; critical $-\mathrm{K}>0,75$. 
We should note that risk modeling enables to conduct a multi-factor analysis, predict possible outcomes of strategic decisions at each stage of the model, evaluate the impact of individual risk factors on its overall size, and choose the best solution for implementing the "road map" model for promoting the MP to the market as a whole.

It should be noted that the process of composing "road maps" for promoting a new MP has not been fully unified yet. Each pharmaceutical enterprise applies a creative approach in accordance with its own level of innovation and investment potential and strategic goals.

\section{CONCLUSIONS AND PROSPECTS FOR FURTHER RESEARCH}

1. We have determined the significance of the "road maps" as one of the main tools for shaping a strategy which gives a clear idea of the scenario to develop a new product and fulfills a strategic function of the withdrawal and promotion of a new MP to the market.

2. We have described the range of the "road map" application, which covers not only the business sphere, but also other types of management activities, including public administration.
3. We have also devised the "road map" model for promoting a new MP to the market, which consists of four stages, the practical implementation of which enables a pharmaceutical enterprise to effectively promote the product to the market, gradually making strategic decisions to determine the communicative and economic efficiency of the entire process of promotion.

4. We have suggested the methods of risk modeling in implementing the "road map" model promoting a new MP to the market, which enable conducting a multi-factor analysis, predict possible results of making strategic decisions at each stage of the model.

In terms of scientific and practical importance, further studies may be devoted to the development of universal indicators for evaluating the effectiveness of "road maps".

The suggested version of the "road map" model can be a working document, which should be taken into consideration in order to optimize the process of promoting the pharmaceutical products to the market, in particular, selection and application of separate tools of marketing communications.

Conflict of Interests: authors have no conflict of interests to declare.

\section{REFERENCES}

1. Постанова КМУ від 28 грудня 2016 р. № 1056 «Деякі питання визначення середньострокових пріоритетних напрямів інноваційної діяльності загальнодержавного рівня на 2017-2021 роки» [Електронний peсурс]. - Режим доступу : http://zakon.rada.gov.ua/laws/show/1056-2016- \%D0 \%BF

2. Наукова та інноваційна діяльність України. Інноваційна діяльність промислових підприємств [Електронний ресурс]. - К. : Державна служба статистики України, 2018. - С. 85-172. - Режим доступу : http://www.ukrstat.gov.ua/druk/publicat/kat_u/2018/zb/09/zb_nauka_2017.pdf

3. Крылова, Ю. В. Дорожная карта как инструмент интеграции продуктового и технологического планирования / Ю. В. Крылова // Практический маркетинг. - 2007. - № 5. - С. 15-19.

4. Use of the staged development tool for assessing, planning, and measuring progress in the development of National Public Health Institutes / E. J. Barzilay, H Vandi, S. Binder et al. // Health Secur. - 2018. - Vol. 16 (S1). - P. 18-24. https://doi.org/10.1089/hs.2018.0044

5. An open source pharma roadmap / M. Balasegaram, P. Kolb, J. McKew et al. // PLoS Med. - 2017. - Vol. 14 (4). https://doi.org/10.1371/journal.pmed.1002276

6. Roadmap for investigating epigenome deregulation and environmental origins of cancer / Z. Herceg, A. Ghantous, C. P. Wild et al. // Int. J. Cancer. - 2018. - Vol. 142 (5). - P. 874-882. https://doi.org/10.1002/ijc.31014

7. Посилкіна, О. В. Економіка і організація інноваційної діяльності: навч. посіб. для студ. вищ. навч. закладів / О. В. Посилкіна, Г. В. Костюк, В. М. Тіманюк. - Х. : НФаУ; Золоті сторінки, 2009. - 272 с.

8. Посилкіна, О. В. Управління проектами у фармацевтичному виробництві / О. В. Посилкіна, Я. М. Деренська, Г. В. Костюк. - Х. : НФаУ, 2010. - 543 с.

9. Фармація України. Погляд у майбутнє : матеріали VII Нац. з'їзду фармацевтів / ред. кол.: В. П. Черних (голова) та ін. - Х.: НФаУ, 2010. - Т. 1. - 600 с.

10. Байгуш, Ю. В. Обгрунтування економічної ефективності та комерційної доцільності впровадження нового антигіпертензивного препарату / Ю. В. Байгуш, М. М. Слободянюк, О. С. Самборський // Управління якістю в фармації: зб. наук. праць Х наук.-практ. конф. за міжнар. участю (м. Харків, 20 травня 2016 р.) / ред. кол. : В. О. Лебединець, Ю. В. Підпружников, Ю. І. Губін та ін. - Х. : НФаУ, 2016. - C. $18-20$.

11. Слободянюк, М. М. Особливості підходів до визначення вартості та фінансування розробок інноваційних лікарських засобів / М. М. Слободянюк, О. С. Самборський // Сучасні досягнення фармацевтичної технології та біотехнології : матеріали $\mathrm{V}$ наук.-практ. інтернет-конф. за міжнар. участю (м. Харків, 18 листопада 2016 р.). - Х. : НФаУ, 2016. - С. 557-560. 
12. Клунко, Н. С. Класифікація інновацій фармацевтичного виробництва України на основі матричного підходу / Н. С. Клунко // БІЗНЕСІНФОРМ. - 2012. - № 2. - С. 61-66.

13. Клунко, Н. С. Роль інноваційного чинника в економічному зростанні фармацевтичних підприємств / Н. С. Клунко // БІЗНЕСІНФОРМ. - 2012. - № 5. - С. 72-75.

14. Слободянюк, М. М. Теоретичні основи і методичне обгрунтування комплексного аналізу та моделювання доцільності й ефективності розробок нових лікарських засобів / М. М. Слободянюк, О. С. Самборський, Т. Германовскі // Соціальна фармація в охороні здоров’я. - 2017. - Т. 3, № 4. - С. 19-31. https://doi.org/10.24959/sphhcj.17.95

15. Гребеник, К. 91 \% препаратів на українському ринку - це генерики [Електронний ресурс] / К. Гребеник. - Режим доступу : https://mind.ua/publications/20184375-91-preparativ-na-ukrayinskomu-rinkuce-generiki

16. Байков, Е. А. Внедрение инновационных технологий дорожного картирования в практику стратегического управления предприятием [Електронний ресурс] / Е. А. Байков // Экономический портал. - Режим доступу : http://institutiones.com/innovations/2432-vnedrenie-innovacionnyx-texnologiydorozhnogo-kartirovaniya.html

17. Грузєва, Т. С. Інноваційна сутність та стратегічний і практичний потенціал нової європейської політики «Здоров’я - 2020» / Т. С. Грузєва // Вісник проблем біології і медицини. - 2014. - Вип. 3, T. 1 (110). - С. 25-33.

18. Кабмин опубликовал дорожную карту по улучшению позиций Украины в рейтинге Doing Business [Електронний ресурс] // Дніпровське інвестиційне агентство. - Режим доступу : http://dia.dp.gov.ua/ ru/kabmin-opublikoval-dorozhnuyu-kartu-po-uluchsheniyu-pozicij-ukrainy-v-rejtinge-doing-business/

19. Указ Президента України від 12 січня 2015 року № 5/2015 «Про Стратегію сталого розвитку «Україна - 2020» [Електронний ресурс] // Офіційний сайт ВР України. - Режим доступу : http://zakon4. rada.gov.ua/laws/show/5/2015

20. Здоровье 2020 : основы европейской политики и стратегии для XXI века [Електронний ресурс] / Всемирная организация здравоохранения, 2013. - 224 с. - Режим доступу : http://www.euro.who. int/_data/assets/pdf_file/0017/215432/Health2020-Long-Rus.pdf?ua=1

21. PSM (Рrice Sensitivity Meter или метод Ван-Вестендорпа) [Електронний ресурс]. - Режим доступу : http://www. businessanalytica.ru/ArticleView.aspx?SectionId=57ec51e9-89d5-468d-96b1-a68ecf82fd85\&ItemId=e4739d72$331 \mathrm{e}-4 \mathrm{~b} 9 \mathrm{a}-989 \mathrm{c}-\mathrm{d} 3 \mathrm{c} 7 \mathrm{bb} 68 \mathrm{ed} 01$

22. 4 метода исследования ценообразования для оптимизации продаж [Електронний ресурс] // LPgenerator. - 2016. - Режим доступу : https://pgenerator.ru/blog/2016/01/27/4-metoda-issledovaniya-cenoobrazovaniyadlya-optimizacii-prodazh/

23. Методы оценки и снижение инновационных рисков [Електронний ресурс]. - Режим доступу : https://studbooks.net/73439/investirovanie/metody_otsenki_snizhenie_innovatsionnyh_riskov

\section{REFERENCES}

1. Postanova KMU vid 28 hrudnia 2016 r. № 1056. (2016). «Deiaki pytannia vyznachennia serednostrokovykh priorytetnykh napriamiv innovatsiinoi diialnosti zahalnoderzhavnoho rivnia na 2017-2021 roky». Available at: https://zakon.rada.gov.ua/laws/show/1056-2016-\%D0\%BF

2. Naukova ta innovatsiina diialnist Ukrainy. Innovatsiina diialnist promyslovykh pidpryiemstv. (2018). Kyiv: Derzhavna sluzhba statystyky Ukrainy, 85-172. Available at: https://www.ukrstat.gov.ua/druk/publicat/ kat_u/2018/zb/09/zb_nauka_2017.pdf

3. Krylova, Ju. V. (2007). Prakticheskij marketing, 5, 15-19.

4. Barzilay, E. J., Vandi, H., Binder, S., Udo, I., Ospina, M. L., Ihekweazu, C., \& Bratton, S. (2018). Use of the Staged Development Tool for Assessing, Planning, and Measuring Progress in the Development of National Public Health Institutes. Health Security, 16(S1), 18-24. https://doi.org/10.1089/hs.2018.0044

5. Balasegaram, M., Kolb, P., McKew, J., Menon, J., Olliaro, P., Sablinski, T., ... Wilbanks, J. (2017). An open source pharma roadmap. PLOS Medicine, 14(4), e1002276. https://doi.org/10.1371/journal.pmed.1002276

6. Herceg, Z., Ghantous, A., Wild, C. P., Sklias, A., Casati, L., Duthie, S. J., ... Hernandez-Vargas, H. (2017). Roadmap for investigating epigenome deregulation and environmental origins of cancer. International Journal of Cancer, 142(5), 874-882. https://doi.org/10.1002/ijc.31014

7. Posylkina, O. V., Kostiuk, H. V., Timaniuk, V. M. (2009). Ekonomika i orhanizatsiia innovatsiinoi diialnosti: navchalnyi posibnyk dlia studentiv vyshchykh navchalnykh zakladiv. Kharkiv: NFaU: Zoloti storinky, 272.

8. Posylkina, O. V., Kostiuk, H. V., Derenska, Ya. M. (2010). Upravlinnia proektamy u farmatsevtychnomu vyrobnytstvi. Kharkiv: NFaU, 543.

9. Chernykh, V. P. (Ed). Farmatsiia Ukrainy. Pohliad u maibutnie : materialy VII Nats. z'izdu farmatsevtiv. (2010). Kharkiv: NFaU, 1, 600 . 
10. Baihush, Yu. V., Slobodianiuk, M. M., Samborskyi, O. S. (2016). Upravlinnia yakistiu v farmatsii: zbirnyk naukovykh prats X naukovo-praktychnoi konferentsii $z$ mizhnarodnoiu uchastiu (20. 04. 2016). Kharkiv: $\mathrm{NFaU}, 18-20$.

11. Slobodianiuk, M. M., Samborskyi, O. S. (2016). Suchasni dosiahnennia farmatsevtychnoi tekhnolohii ta biotekhnolohii : materialy V naukovo-praktychnoi konferentsii z mizhnarodnoiu uchastiu (18.11.2016). Kharkiv: $\mathrm{NFaU}, 557-560$.

12. Klunko, N. S. (2012). BIZNESINFORM, 2, 61-66.

13. Klunko, N. S. (2012). BIZNESINFORM, 5, 72-75.

14. Slobodyanyuk, M., Samborskyi, O., \& Hermanowski, T. (2017). The theoretical fundamentals and methodical substantiation of the complex analysis and modeling of expediency and efficiency when developing new medicines. Social'na farmaciâ v ohoronì zdorov'â, 3(4), 19-31. https://doi.org/10.24959/sphhcj.17.95

15. Hrebenyk, K. (2018). 91 \% preparativ na ukrainskomu rynku - tse heneryky. Available at: https://mind.ua/ publications/20184375-91-preparativ-na-ukrayinskomu-rinku-cegeneriki

16. Baikov, E. A. (n.d.). Ekonomicheskii portal. Available at: http://institutiones.com/innovations/2432-vnedrenie-innovacionnyx-texnologiy-dorozhnogo-kartirovaniya.html

17. Hruzieva, T. S. (2014). Visnyk problem biolohii i medytsyny, 3(1(110)), 25-33.

18. Kabmin opublikoval dorozhnuiu kartu po uluchsheniiu pozitcii Ukrainy v reitinge Doing Business. (n.d.). Dniprovske investytsiine ahentstvo. Available at: http://dia.dp.gov.ua/ru/kabmin-opublikoval-dorozhnuyukartu-po-uluchsheniyu-posicij-ukrainy-v-rejtinge-doing-business/

19. Ukaz Prezydenta Ukrainy vid 12 sichnia 2015 roku № 5/2015. (2015). «Pro Stratehiiu staloho rozvytku «Ukraina - 2020». Ofitsiinyi sait VR Ukrainy Available at: https://zakon4.rada.gov.ua/laws/show/5/2015

20. Zdorove 2020: osnovb evropeiskoi polytyky y stratehyy dlia XXI veka. (2013). Vsemyrnaia orhanyzatsyia zdravookhranenyia, 224. Available at: http://www.euro.who.int/_data/assets/pdf_file/0017/215432/Health2020Long-Rus.pdf?ua $=1$

21. PSM (Price Sensitivity Meter ili metod Van-Vestendorpa). (n.d.). Available at: http://www.businessanalytica.ru/ ArticleView.aspx?SectionId=57ec51e9-89d5-468d-96b1-a68ecf82fd85\&ItemId=e4739d72-331e-4b9a$989 \mathrm{c}-\mathrm{d} 3 \mathrm{c} 7 \mathrm{bb} 68 \mathrm{ed} 01$

22. 4 metoda issledovaniia tcenoobrazovaniia dlia optimizatcii prodazh. (2016). LPgenerator. Available at: https://lpgenerator.ru/blog/2016/01/27/4-metoda-issledovaniya-cenoobrazovaniya-dlya-optimizaciiprodazh/

23. Metody otcenki i snizhenie innovatcionnykh riskov. (n.d.). Available at: https://studbooks.net/73439/ investirovanie/metody_otsenki_snizhenie_innovatsionnyh_riskov

Адреса для листування:

61168, м. Харків, вул. Валентинівська, 4 .

Надійшла до редакції 31.03.2019 p.

Тел. (0572) 67-91-72. E-mail: angelika.olkhovskaya@gmail.com.

Національний фармацевтичний університет

Ольховська А. Б. (ORCID - http://orcid.org/0000-0002-0237-5741)

Малий В. В. (ORCID - https://orcid.org/0000-0002-6028-1890) 